\title{
Treatment of Heart Block in Children
}

\author{
RODNEY BLUESTONE^, ALAN HARRIS, and SAM TUCKER \\ From St. George's Hospital, London S.W.1
}

Congenital or acquired complete heart block, though a rare disease in childhood, may raise difficult problems of management. Congenital complete heart block is compatible with normal development and survival (Yater, 1929; Campbell and Thorne, 1956; Donoso, Braunwald, Jick, and Grushman, 1956; Ikkos and Hanson, 1960; Hill, 1963; Nakamura and Nadas, 1964), but there is no doubt that Stokes-Adams attacks, though rare, can occur, and probably reflect a poor prognosis (Smithells and Outon, 1959; Molthan, Miller, Hastreiter, and Paul, 1962; Nakamura and Nadas, 1964).

The surgical correction of congenital abnormalities particularly ventricular septal defect, produced a number of instances of complete heart block, and though the incidence of this complication has decreased with improved techniques, it still occasionally occurs, and if associated with Stokes-Adams attacks is reported to have a high mortality (Reemtsma, Delgado, and Creech, 1960; McGoon, Ongley, and Kirklin, 1964a). In recent years efforts have been made to provide post-operative and long-term treatment for post-operative heart block (Brockman, Webb, and Bahnson, 1958; Weirich and Roe, 1961; Lillehei, Levy, Bonnabeau, Long, and Sellers, 1964a, b), since up until now it has generally been agreed that the prognosis is so poor that artificial pacing should always be instituted. Stokes-Adams attacks in children with non-surgical heart block can, however, be controlled with isoprenaline-1-a ('saventrine'), and it is possible that drug therapy may avoid pacing in some cases of post-surgical block. We now report our experience with the treatment of 3 children with heart block.

\section{Material and Methods of Treatment}

All three were boys, two aged 4 and the other $1 \frac{1}{2}$ years. One patient had congenital heart block; two had acquired heart block, one following incomplete surgical correction of Fallot's tetralogy (residual ventricular septal defect), and the other possibly from an acute myocarditis.

Received February 16, 1966.

* Supported by a grant from the British Heart Foundation.
The indication for treatment in Cases 1 and 2 was the presence of Stokes-Adams attacks. In Case 3 the indication was the poor prognosis of surgically-acquired complete heart block.

Most of the technique developed for the treatment of adult atrioventricular block (Bluestone and Harris, 1965; Harris, Bluestone, Busby, Davies, Leatham, Siddons, and Sowton, 1965) can be applied to children. The management of Stokes-Adams attacks in children is summarized in the Table. External cardiac massage and assisted pulmonary ventilation is frequently effective in restoring idioventricular rhythm; external pacing with stimuli of up to 200 volts applied across the intact chest,

TABLE

\section{Management of Stokes-Adams Attacks}

\section{Acute Management of Attacks}

(1) Sharp blow on praecordium may restore heart beat

(2) External cardiac massage

(3) Clear airways and assist respiration if necessary

(4) If attacks due to asystole, external pacing (up to 200 volts)

(5) Speed idioventricular rate with isoprenaline infusion $1 \mathrm{mg}$. in $500 \mathrm{ml}$. dextrose at 10-20 drops per minute; stop or slow infusion rate if many ectopics or runs of ventricular tachyarrhythmia occur

(6) Endocardial pacing via ante-cubital fossa or femoral veins

Long-term Management
(1) Long-acting isoprenaline up to $30 \mathrm{mg}$. 4-hourly, nocturnal doses are usually unnecessary, but a late evening dose of ephedrine or long-acting isoprenaline suppository if rate drops excessively; if heart failure is present addition of a diuretic and digitalis (provided the heart block is complete)

(2) Long-term epicardial pacing

using a simple condenser discharge unit, never failed to start the heart when used promptly on patients with asystole. External pacing, however, is painful on return of consciousness due to contraction of chest wall muscles and the occurrence of skin burns, and if external pacing is continued general anaesthesia is necessary. Stokes-Adams attacks due to asystole may be completely prevented by intravenous isoprenaline, but if the underlying rhythm is paroxysmal ventricular tachycardia or fibrillation, isoprenaline may worsen the situation. If a satisfactory response to intravenous isoprenaline is maintained, treatment with long-acting isoprenaline (isoprenaline-1-a) up to $30 \mathrm{mg}$. 4-hourly, should be started, and the patient should be observed in hospital, for at least two weeks, in order to assess its 
effectiveness. Experience gained from the treatment of adults with $\mathrm{A}-\mathrm{V}$ block has shown that atropine, ephedrine, chlorothiazide, and steroid therapy are not effective in the long-term prevention of Stokes-Adams attacks (Bluestone and Harris, 1965). If Stokes-Adams attacks continue despite adequate doses of isoprenaline-1-a, then recourse has to be made to long-term artificial pacing. An endocardial system of artificial pacing may be needed temporarily, and indeed is the method of choice for longterm pacing in adults (Harris et al., 1965), but an epicardial system with an implanted pacemaker seems preferable in children.

In the absence of Stokes-Adams attacks treatment may still be required if the patient's exercise tolerance is severely impaired by the slow rate. This usually implies that some additional myocardial disease is present to account for the onset of heart failure. Isoprenaline-1-a alone is not successful in the treatment of heart failure, and the addition of a diuretic and digitalis (provided the heart block is complete) is always necessary.

\section{Case Reports}

Case 1. This boy, born by caesarean section because of foetal distress, had, since birth, a slow heart rate due to complete heart block, but he was asymptomatic until the onset of Stokes-Adams attacks when he was 4 years old. On examination he was a well-developed infant, the heart was normal in size with a moderately loud ejection systolic murmur maximal at the base, attributed to an increased stroke volume; there were no other signs of a cardiac lesion. The ECG showed complete heart block with a ventricular rate of $\mathbf{4 0}$ per minute. Treatment was started with ephedrine $15 \mathrm{mg}$. t.d.s. The evening dose of ephedrine resulted in nervousness and sleeplessness. Further Stokes-Adams attacks occurred when he was 6 years, and isoprenaline-1-a was started $30 \mathrm{mg}$. 4-hourly (omitting night doses), and ephedrine therapy was omitted. The ventricular rate increased from 40 to 50 per minute and no further Stokes-Adams attacks have occurred during the past 2 years.

Case 2. This boy was the product of a normal fullterm delivery. He was first seen at the age of 18 months following 6 episodes of loss of consciousness which had started 10 days after smallpox vaccination, raising the possibility that his heart lesion resulted from a myocarditis. At this time he was found to be in complete heart block with a ventricular rate of 32 per minute. The heart was moderately enlarged with very loud harsh ejection systolic and apical mid-diastolic murmurs. The ECG showed complete atrio-ventricular block and steep $T$ wave inversion in leads II, III, V2, and V3. There was no evidence of any active systemic illness. The ventricular rate increased to 70 per minute and the attacks stopped, using intravenous infusion of isoprenaline. When the drip rate was increased numerous ventricular ectopic beats and episodes of ventricular tachycardia occurred, but were stopped by slowing the drip rate. With a ventricular rate of 70 per minute the apical systolic and diastolic murmurs could no longer be heard, indicating that they were due to the slow heart rate. Treatment was continued with isoprenaline-1-a suppositories $15 \mathrm{mg}$. q.d.s., and subsequently with oral isoprenaline-1-a $30 \mathrm{mg}$. q.d.s. Although he tended to chew this preparation, thereby losing some of its sustained-release effect, the pulse rate rose to $40-55$ per minute, and after 12 months' treatment he has remained well and free from Stokes-Adams attacks.

Case 3. This boy had Fallot's tetralogy. When he was 4 years of age an operation to correct these abnormalities was complicated by complete heart block. No Stokes-Adams attacks occurred, but in view of the poor prognosis of surgically-acquired heart block artificial pacing was recommended. An epicardial electrode was inserted and attached to an implanted abdominal unit 5 months after the open-heart operation. Early failure of pacing, requiring reimplantation of the pacemaker unit and electrodes, was later followed by sepsis and rejection of the pacemaker unit. For 12 months pacing was continued with an external unit attached to the epicardial wires exteriorized on the anterior abdominal wall. There was a gradual rise in the threshold (power requirement) for pacing owing to sepsis around the epicardial electrodes, and pacing had to be abandoned. Rather than advise a fourth thoracotomy for reimplantation of a pacing system, the child was then left unpaced. He has been untreated for 18 months and is active and well and symptom free, though he does have a residual ventricular septal defect. The idioventricular rate remains at $65 /$ minute.

\section{Discussion}

Congenital heart block, in the absence of StokesAdams attacks, is usually benign (Nakamura and Nadas, 1964), and treatment is not indicated. Acquired heart block in children is less benign, and the occurrence of Stokes-Adams attacks raises doubt about the prognosis in heart block of any aetiology; thus both in Case 1 with congenital heart block, and in Case 2 with conduction defect which might have been due to recent myocarditis, the presence of Stokes-Adams attacks indicated an urgent need for specific treatment. Both patients have so far responded satisfactorily to isoprenaline-1-a with complete suppression of Stokes-Adams attacks, in agreement with our experience of treatment of Stokes-Adams attacks in some adults with isoprenaline-1-a (Bluestone and Harris, 1965). It is difficult to prevent young children from chewing the isoprenaline-l-a tablet, and this may upset the longacting properties; under these circumstances suppositories may be useful. If treatment is needed, it is essential to maintain regular dosage; this requires the co-operation of the parents and education authorities. Up to now there has been general agreement that long-term pacing is necessary for post-surgical heart block, particularly if it is 
associated with Stokes-Adams attacks (Reemtsma et al., 1960; Lauer, Ongley, DuShane, and Kirklin, 1960; Lillehei et al., 1964a, b; McGoon, Ongley, and Kirklin, 1964b), and often for Stokes-Adams attacks secondary to congenital or other acquired types of heart block. Experience with isoprenaline-1-a, however, has shown that it is possible to avoid artificial pacing in many adult patients (Bluestone and Harris, 1965), and this is confirmed by the results of treatment in two children (Case 1 and 2). In view of this experience, treatment of postsurgical heart block with isoprenaline-l-a might be an acceptable alternative to pacing in some patients.

Long-term artificial pacing in our experience is fraught with many difficulties and complications (Harris et al., 1965) and Case 3 illustrates many of these problems. The incidence of sepsis and pacemaker rejection, in our experience, has been high with the epicardial electrode with an implanted abdominal pacemaker in adults (Harris et al., 1965), and this factor combined with the advantages of avoiding a thoracotomy has resulted in the wider use of endocardial pacing with an implanted pacemaker (Bluestone, Davies, Harris, Leatham, and Siddons, 1965). The use of an endocardial electrode for long-term pacing was thought not to be suitable for infants and children, since it would not be possible to allow for growth when positioning the electrode catheter in the right ventricle. Other centres (Chardack, Gage, Federico, Schimert, and Greatbatch, 1964; Nathan, Center, Samet, $W u$, and Keller, 1964; Zoll, Frank, and Linenthal, 1964) appear to have had a better experience with epicardial pacing and implanted pacemaker, with a much lower incidence of sepsis and unit rejection and this seems to be the method of choice in children. Even with satisfactory pacing careful followup is essential, and it is difficult to avoid the occurrence of a tremendous stress due to anxiety both in the patient and in the parents. In our paced patient frequent breakdowns occurred in the pacing system requiring many emergency admissions to hospital which disrupted his entire family's life. Since pacing has been abandoned, the child has remained well, and possibly the institution of longterm pacing was unnecessary in the first instance since Stokes-Adams attacks had not occurred. As a general rule long-term pacing should only be recommended if Stokes-Adams attacks occur and are not completely abolished by a full therapeutic trial with isoprenaline-1-a.

An ejection systolic murmur was heard in two of the patients, and one had, in addition, a loud apical mid-diastolic murmur. These signs must have been due to a large stroke volume consequent on a slow rate, for there was no evidence of associated cardiac disease. With an increased heart rate the ejection murmur became much softer in one patient and entirely disappeared in the other, as did the middiastolic murmur.

An important consideration in the management of heart disease in infants and children is the psychological adjustment that has to be made by the parents. In complete heart block without Stokes-Adams attacks, probably no treatment is necessary and the child's upbringing should be as normal as possible. When treatment is necessary many difficulties have been encountered, as exemplified by Case 1 (before treatment) where the parents took it in turns to keep a day and night watch on their child, and insisted on only allowing attendance at a school where the teachers were able to perform external cardiac massage! Treatment with isoprenaline-1-a has prevented further Stokes-Adams attacks, and with the knowledge that attacks never seem to occur during sleep the parents' anxiety has been relieved and their child is leading a more normal life.

\section{Summary}

Three children with complete heart block are described, one with congenital heart block and two with acquired heart block. The indication for treatment is the occurrence of Stokes-Adams attacks and the emergency and long-term management is described.

In view of the complications associated with longterm artificial pacing, isoprenaline-l-a ('saventrine') should always be tried in the first instance to control Stokes-Adams attacks.

We wish to thank Dr. Charles Pinckney and Dr. Aubrey Leatham for permission to study their patients.

\section{REFERENCES}

Bluestone, R., Davies, G., Harris, A., Leatham, A., and Siddons, H. (1965). Long-term endocardial pacing for heart-block. Lancet, 2, 307.

acting isoprenaline. ibid., 1, 1299.

Brockman, S. K., Webb, R. C., Jr., and Bahnson, H. T. (1958). Monopolar ventricular stimulation for the control of acute surgically produced heart block. Surgery, 44, 910.

Campbell, M., and Thorne, M. G. (1956). Congenital heart block. Brit. Heart F., 18, 90.

Chardack, W. M., Gage, A. A., Federico, A. J., Schimert, G., and Greatbatch, W. (1964). Clinical experience with an implantable pacemaker. Ann. N.Y. Acad. Sci., 111, 1075.

Donoso, E., Braunwald, E., Jick, S., and Grushman, A. (1956). Congenital heart block. Amer. f. Med., 20, 869.

Harris, A., Bluestone, R., Busby, E., Davies, G., Leatham, A. Siddons, H., and Sowton, E. (1965). The management of heart block. Brit. Heart f., 27, 469.

Hill, I. G. W. (1963). Some less familiar forms of heart disease. Scot. med. f., 8, 331.

Ikkos, D., and Hanson, J. S. (1960). Response to exercise in congenital complete atrioventricular block. Circulation, 22, 583. 
Lauer, R. M., Ongley, P. A., DuShane, J. W., and Kirklin, J. W. (1960). Heart block after repair of ventricular septal defect in children. ibid., 22, 526.

Lillehei, C. W., Levy, M. J., Bonnabeau, R. C., Jr., Long, D. M., and Sellers, R. D. (1964a). The use of a myocardial electrode and pacemaker in the management of acute postoperative and postinfarction complete heart block. Surgery, 56, 463.

,,,---- , and - - (1964b). Direct wire electrical stimulation for acute postsurgical and postinfarction complete heart block. Ann. N.Y. Acad. Sci., 111, 938.

McGoon, D. C., Ongley, P. A., and Kirklin, J. W. (1964a). Surgically induced heart block. ibid., 111, 830 .

,-- , and - (1964b). Surgical heart block. Amer.F. Med., 37, 749.

Molthan, M. E., Miller, R. A., Hastreiter, A. R., and Paul, M. H. (1962). Congenital heart block with fatal Adams-Stokes attacks in childhood. Pediatrics, 30, 32.
Nakamura, F. F., and Nadas, A. S. (1964). Complete heart block in infants and children. New Engl. F. Med., 270, 1261.

Nathan, D. A., Center, S., Samet, P., Wu, C. Y., and Keller, J. W., Jr. (1964). The application of an implantable synchronous pacer for the correction of Stokes-Adams attacks. Ann. N.Y. Acad. Sci., 111, 1093.

Reemtsma, N., Delgado, J. P., and Creech, O. (1960). Heart block following intracardiac surgery: Localisation of conduction tissue injury. 7 . thorac. cardiovasc. Surg., 39, 688.

Smithells, R. W., and Outon, E. B. (1959). Congenital heart block. Arch. Dis. Childh., 34, 223.

Weirich, W. L., and Roe, B. B. (1961). The role of pacemakers in the management of surgically induced heart block. Amer. F. Surg., 102, 293.

Yater, W. M. (1929). Congenital heart block. Amer. F. Dis. Child., 38, 112.

Zoll, P. M., Frank, H. A., and Linenthal, A. J. (1964). Implantable cardiac pacemakers. Ann. N.Y. Acad. Sci., 111, 1068. 